\title{
The influence of ultrafine-grained structure on the mechanical properties and biocompatibility of austenitic stainless steels
}

\author{
Olga V. Rybalchenko ${ }^{1,2}$ (- | Natalia Yu. Anisimova,3 | Mikhail V. Kiselevsky ${ }^{2,3}$ | \\ Andrey N. Belyakov ${ }^{4}$ | Aleksei A. Tokar ${ }^{1,2}$ | Vladimir F. Terent'ev ${ }^{1}$ | \\ Dmitry V. Prosvirnin $^{1}$ | Georgy V. Rybalchenko ${ }^{5}$ | Georgi I. Raab ${ }^{6}$ | \\ Sergey V. Dobatkin ${ }^{1,2}$
}

${ }^{1}$ A. A. Baikov Institute of Metallurgy and Materials Science of RAS, Moscow, Russia

${ }^{2}$ National University of Science and

Technology "MISIS", Laboratory of Hybrid

Nanostructured Materials, Moscow, Russia

3"N. N. Blokhin National Medical Research Centre of Oncology" of the Health Ministry of Russia, Moscow, Russia

${ }^{4}$ Belgorod State University, Belgorod, Russia

${ }^{5}$ P.N. Lebedev Physical Institute of RAS,

Moscow, Russia

${ }^{6}$ Ufa State Aviation Technical University, Institute of Physics of Advanced Materials, Ufa, Russia

\section{Correspondence}

Olga V. Rybalchenko, A. A. Baikov Institute of Metallurgy and Materials Science of RAS, Leninsky prospect, 49, 119334 Moscow, Russia.

Email: rybalch@mail.ru

Funding information

Basic Research Program of the Presidium of the Russian Academy of Sciences, Grant/ Award Number: 37 P; governmental task, Grant/Award Number: 075-00746-19-00; Russian Foundation for Basic Research, Grant/ Award Number: grant 16-08-00365-a

\begin{abstract}
In this study, equal-channel angular pressing (ECAP) of austenitic $316 \mathrm{~L}$ and $\mathrm{Cr}-\mathrm{Ni}-\mathrm{Ti}$ stainless steels was carried out. Effect of ECAP at $400^{\circ} \mathrm{C}$ on the evolution of the microstructure, mechanical properties, and biocompatibility of these steels was investigated. The biocompatibility of samples with the ultrafine grain structure obtained in the ECAP process did not deteriorate in comparison with an austenitic $316 \mathrm{~L}$ stainless steel in coarse-grained state. However, this treatment enhances the multipotent mesenchymal stromal/stem cell proliferation by $26 \%$ for $316 \mathrm{~L}$ steel and by $17 \%$ for $\mathrm{Cr}-\mathrm{Ni}$-Ti stainless steel in comparison with coarse-grained counterparts. At the same time, ECAP contributes to a significant improvement in performance and weight reduction of medical devices, which is especially important for the creation of implanted prostheses for replacement of skeletal defects, due to significant increase in specific strength of steels. The strength properties of austenitic stainless steels were remarkably improved due to the grain refinement and deformation twinning resulted from ECAP at $400^{\circ} \mathrm{C}$. After ECAP, the yield strength of $316 \mathrm{~L}$ and $\mathrm{Cr}-\mathrm{Ni}-\mathrm{Ti}$ stainless steels increased by 4.2 and 2.9 times up to 950 and $900 \mathrm{MPa}$, and the fatigue limit by 2 and 1.7 times up to 500 and $475 \mathrm{MPa}$, respectively, comparing to coarse-grained counterparts.
\end{abstract}

\section{KEYWORDS}

austenitic stainless steels, biocompatibility in vitro, equal-channel angular pressing, strength and fatigue properties, ultrafine grained structures

\section{1 | INTRODUCTION}

Austenitic stainless steels have a high complex of service properties, therefore they are widely used not only as a constructional material, but also as a biomedical material (Davies, 2003). They are successfully used for the manufacture of internal fixation devices, surgical instruments, implants for use in orthopedics, dentistry (Niinomi, Nakai, \& Hieda, 2012) and for vascular implants (Okazaki \& Goth, 2008; Thierry, Merhi, Bilodeau, Trépanier, \& Tabrizian, 2002). The advantages of convenient for use and production of austenitic stainless steels as a biomedical material together with high strength, ductility, and corrosion resistance are biocompatibility and relatively low cost (Mantripragada, Lecka-Czernik, Ebraheim, \& Jayasuriya, 2013).

An austenitic stainless steel $316 \mathrm{~L}$ with a composition of $18 \%$ $\mathrm{Cr}-14 \% \mathrm{Ni}-2.5 \% \mathrm{Mo}$ is mainly used as a biomedical material for implantable products. The nickel content in this steel is significantly higher than in conventional austenitic steel that ensures a fully austenitic state (Yamamoto, Kohama, Kuroda, \& Hanawa, 2004). However, a 
large amount of nickel is the main problem for using the steel as a biomedical material, since nickel and its compounds are strong allergens (Narayan, 2009).

With the development of medicine, the main task of specialists in materials science and medical technology is the development of biomedical materials with enhanced mechanical and operational characteristics to ensure the long-term integrity of the implant. Therefore, fatigue strength and biocompatibility are the most important properties of a material for an implantable product. It is known that fatigue failure is the main reason of damage to a steel implant (Teoh, 2000). At the same time, the fatigue strength $\left(\sigma_{f}\right)$ of austenitic $316 \mathrm{~L}$ stainless steel is one of the lowest among the alloys used for orthopedic implants (Teoh, 2000).

The possibility of increasing the mechanical and performance characteristics, including durability under high-cycle fatigue conditions due to the ultrafine-grained (UFG) structure in austenitic stainless steels after severe plastic deformation using the equal channel angular pressing (ECAP) was proved (Dobatkin, Rybal'chenko, \& Raab, 2007; Dong et al., 2013; Huang, Yang, Gao, Wu, \& Zhang, 2008; Ueno, Kakihata, Kaneko, Hashimoto, \& Vinogradov, 2011). Increasing the specific strength of UFG steel at static and cyclic loads will significantly reduce the weight of implanted products in contrast to conventional coarse-grained steels.

In addition, it is known that the nano/ultrafine grained structure in such materials, as ceramics (Webster, Ergun, Doremus, Siegel, \& Bizios, 2000; Webster, Siegel, \& Bizios, 1999), composites (Kay, Thapa, Haberstroh, \& Webster, 2002; McManus, Doremus, Siegel, \& Bizios, 2005), and polymers (Thapa, Webster, \& Haberstroh, 2003; Webster \& Smith, 2005) stimulates cellular activity upon contact with living tissues. In pure titanium the UFG structure obtained using severe plastic deformation by high-pressure torsion (Faghihi, Azari, Zhilyeav, Vali, \& Tabrizian, 2007a; Faghihi, Azari, Zhilyeav, Vali, \& Tabrizian, 2007b) significantly increases cell adhesion and metabolic activity compared to the coarse-grained structure. The authors (Faghihi et al., 2007a; Faghihi et al., 2007b) explain this effect by the increased wettability of the oxide layer formed on the surface of ultrafine-grained titanium. The work (Misra et al., 2009a; Misra et al., 2009b) confirms that cell attachment, proliferation, viability, morphology, and spread on a substrate made of 316L steel with a UFG structure obtained by cold rolling and subsequent annealing are favorably modulated and significantly vary from the cell behavior on steel substrates in a coarse-grained condition. The difference in the behavior of cells is explained in the work (Misra et al., 2009a; Misra et al., 2009b; Nune, Montes, Injeti, Somani, \& Misra, 2018) by the grain size and the degree of hydrophilicity of the steels. The research of $316 \mathrm{~L}$ stainless steel (Muley, Vidvans, Chaudhari, \& Udainiya, 2016) with ultrafine grained structure obtained by multiaxial forging with an average grain size of $0.86 \mu \mathrm{m}$ after nine strain steps revealed improved sliding wear resistance and enhanced pitting resistance of forged steel. Enhanced pitting resistance was ascribed to an increase in the grain boundary volume, and homogenization of pit inducing impurities and nonmetallic phases due to severe deformation, which influenced the passive film properties.

These studies provide the basis for further study of bulk UFG materials in order to estimate the possibilities of creating implantable materials with enhanced performance characteristics in combination with favorable biocompatibility. At the same time, in spite of the complex of unique properties that open up prospects for use of UFG steels in medicine, such materials may create a risk for possible negative effects on the human body. Therefore, for the manufacture of blood-contacting implantable medical devices, their biocompatibility testing in accordance with ISO 10993 is required.

The purpose of this work was to study the mechanical and operational properties of samples of ultrafine-grained austenitic $316 \mathrm{~L}$ and $\mathrm{Cr}$ $\mathrm{Ni}-\mathrm{Ti}$ stainless steels obtained by ECAP. $\mathrm{Cr}-\mathrm{Ni}-\mathrm{Ti}$ steel with the lower nickel content is used to compare the influence of the chemical composition on the structure and properties of steels after ECAP. The ECAP technique was chosen due to the possibility of obtaining bulk steel samples with an ultrafine-grained structure suitable for the production of medical devices. Biocompatibility was assessed by determining cytotoxicity and induced hemolysis $(\mathrm{IH})$. Additionally, the effect of the tested steel samples on the proliferation of multipotent mesenchymal stromal/ stem cells (MMSCs) and the induction of apoptosis were evaluated.

\section{2 | EXPERIMENTAL}

\section{1 | Specimen preparation}

In the study, two austenitic stainless steels were used. The first one was the $316 \mathrm{~L}$ steel with low carbon content recommended for the manufacture of implants. The second one was the $\mathrm{Cr}-\mathrm{Ni}$ - $\mathrm{Ti}$ steel with a lower $\mathrm{Ni}$ content that results in martensitic transformation during cold severe plastic deformation. The nominal composition of the stainless $\mathrm{Cr}-\mathrm{Ni}$ steels is shown in Table 1. The material in as-received condition was austenitized at $1050^{\circ} \mathrm{C}$ for $1 \mathrm{hr}$ and water quenched. ECAP was carried out via route Bc on billets of $20 \mathrm{~mm}$ in diameter and $90 \mathrm{~mm}$ long using a die with channels intersecting at $120^{\circ}$ and a graphite lubricant (Valiev \& Langdon, 2006). For maximum structure refining the samples were processed by six ECAP-passes for $\mathrm{Cr}-\mathrm{Ni}-\mathrm{Ti}$ steel and by eight ECAP-passes for $316 \mathrm{~L}$ at $400^{\circ} \mathrm{C}$. A deformation temperature of $400^{\circ} \mathrm{C}$, exceeding the deformation martensite formation temperature, was chosen to suppress the martensitic transformation in austenitic stainless $\mathrm{Cr}-\mathrm{Ni}-\mathrm{Ti}$ steel during the ECAP process.

TABLE 1 Chemical composition of the $\mathrm{Cr}-\mathrm{Ni}$ stainless steels

\begin{tabular}{|c|c|c|c|c|c|c|c|c|c|c|c|}
\hline \multirow[b]{2}{*}{ Elements } & \multicolumn{11}{|c|}{ Amount (wt \%) } \\
\hline & $\mathrm{C}$ & $\mathrm{Cr}$ & $\mathrm{Ni}$ & $\mathrm{Cu}$ & $\mathrm{Ti}$ & Si & $M n$ & Mo & $\mathbf{N}$ & $S, P$ & $\mathrm{Fe}$ \\
\hline $\mathrm{Cr}-\mathrm{Ni}-\mathrm{Ti}$ steel & 0.07 & 17.3 & 9.2 & 0.2 & 0.7 & 0.6 & 1.4 & - & - & 0.003 & \\
\hline $316 \mathrm{~L}$ & 0.012 & 17.3 & 14.11 & 0.07 & - & 0.24 & 1.77 & 2.75 & 0.07 & $0.001 / 0.024$ & \\
\hline
\end{tabular}


The true strain applied to the billet per pass for the defined die geometry equals 0.9 (shear strain $\gamma=1.5$ ) (Iwahashi, Horita, Nemoto, \& Langdon, 1997; Iwahashi, Wang, Horita, Nemoto, \& Langdon, 1996).

\section{2 | Microstructural characterization}

The microstructure was investigated using a JEM-2100 transmission electron microscope operated at $200 \mathrm{kV}$. Thin foils for transmission electron microscopy (TEM) were mechanically ground to $90 \mu \mathrm{m}$ and thinned to perforation by twinjet electrolytic polisher with a solution of $10 \% \mathrm{HClO}_{4}$ in $\mathrm{CH}_{3} \mathrm{COOH}$ at $25 \mathrm{~V}$. The phase composition, the crystallite size, and the dislocation density were investigated by $\mathrm{X}$-ray diffraction (XRD), which was carried out with an Ultima IV diffractometer with CoK $\alpha 1$ radiation (wave length: $\lambda=1.789 \AA$ ).

\subsection{Evaluation of mechanical and fatigue properties}

The tensile and fatigue specimens with a gage length of $15 \mathrm{~mm}$ and a cross-section of $1.5 \mathrm{~mm} \times 7 \mathrm{~mm}$ were cut by a wire spark cutter from the ECAP billets. The specimens were mechanically polished using SiC grit papers and diamond paste and then electrolytically polished at room temperature (RT) under a voltage of $15 \mathrm{~V}$ for $5 \mathrm{~min}$ in a solution containing $100 \mathrm{~g}$ chromic anhydride and $850 \mathrm{~mL}$ orthophosphoric acid.

The tensile tests were performed at room temperature using an INSTRON 3380 machine with a strain rate $1 \mathrm{~mm} / \mathrm{min}$ and a load capacity of $100 \mathrm{kN}$. The high-cycle fatigue tests were carried out under repeated tension conditions in an INSTRON 8801 servohydraulic machine with a load capacity of $100 \mathrm{kN}$ operated at $40 \mathrm{~Hz}$ testing frequency and a stress ratio of $R=0.1$.

\section{4 | Cell preparation}

Samples in the form of square plates measuring $10 \times 10 \times 0.2 \mathrm{~mm}^{3}$ ground on abrasive paper of various grain sizes (up to $\mathrm{P} 4000$ ) were used for hemocompatibility studies. For sterilization, the samples were immersed for $18-20 \mathrm{hr}$ in $70 \%$ ethanol, and then washed by sterile $0.9 \% \mathrm{NaCl}$ solution.

For study of hemolysis ratio and cytotoxicity the blood of C57BI/ 6 mice stabilized with sodium heparin, $200 \mathrm{lU} / \mathrm{ml}$, was used.

Mononuclear leukocytes (MLs) were separated from blood in interface of Ficoll-Paque gradient $(\rho=1.36)$ (Sigma-Aldrich). Then MLs were washed twice with Dulbecco's modified Eagle's medium (DMEM) (Gibco, Invitrogen) and suspended in DMEM containing 10\% fetal bovine serum (Hy Clon, Thermo Fisher), $4 \mathrm{mM}$ L-glutamine (Gibco) and 1\% penicillin/streptomycin (Gibco). MLs concentration in the suspension was $4.6 \times 10^{4}$ cells $/ \mathrm{ml}$, viability was $92 \%$.

MMSCs were generated from dog bone marrow and characterized as we described early (Senatov et al., 2017). For the studies PI (+) CD34(-)CD45(-)CD105(+) cells of the third passage were used. The trypsinized cells were washed two times with phosphate-buffered saline (PBS) at $200 \mathrm{~g}$ for $5 \mathrm{~min}$ and suspended in growth medium at $37^{\circ} \mathrm{C} 5 \% \mathrm{CO}_{2}$ for 7 days. The concentration of MMSC was $2.4 \times 10^{4}$ cells $/ \mathrm{ml}$ with viability of $88 \%$.
All manipulations and studies with animals were performed according to regulations of the Local Ethics Committee of " $N$. N. Blokhin National Medical Research Centre of Oncology" of the Health Ministry of Russia.

\section{5 | Hemolysis test}

One milliliter of human blood was diluted with $5 \mathrm{ml}$ of $0.9 \%$ salt in PBS containing $0.9 \mathrm{ml}$ sodium citrate (3.8 wt \%). One milliliter of diluted blood was added to well of a 24-well plate (Nung) with steel sample and the plate was incubated for 2.4 and $24 \mathrm{hr}$ at $37^{\circ} \mathrm{C}$. Finally, the diluted blood from each well was centrifuged for $10 \mathrm{~min}$ at $3000 \mathrm{rpm}$. The $0.1 \mathrm{ml}$ supernatant was transferred to a well of 96-well plate (Nung). The optical density (OD) was measured using a plate rider MS Multiscan (Labsystem) at $540 \mathrm{~nm}$. The negative and positive groups were $5 \mathrm{ml}$ of PBS with $0.1 \mathrm{ml}$ of diluted blood and $5 \mathrm{ml}$ of distilled water with $0.1 \mathrm{ml}$ of diluted blood, respectively. The hemolysis ratio was evaluated as described early (Senatov et al., 2017).

\subsection{Cytotoxicity test}

The steel samples were incubated with $M L$ in the growth medium in 24-well culture plates ("Costar," USA) for $24 \mathrm{hr}$ under $5 \% \mathrm{CO}_{2}$ and saturated humidity at $37^{\circ} \mathrm{C}$. After the incubation, $20 \mu \mathrm{L}$ 3-(4,5-dimethylthiazol-2-yl)-2,3-(4,5-dimethylthiazol-2-yl)-2.5-diphenyltetrazolium bromide (MTT) (Sigma) with a concentration of $5 \mathrm{mg} / \mathrm{ml}$ was added into each well. The plates were incubated for $4 \mathrm{hr}$ under the same conditions of atmosphere and temperature. After the replacement, the medium with MTT $500 \mu \mathrm{L}$ dimethyl sulfoxide (DMSO) was added to wells to dissolve the formazan crystals. OD measurements were conducted using a plate rider MS Multiscan (Labsystem) at $540 \mathrm{~nm}$ in triplicate of 96-well plates. Cytotoxicity was evaluated as described early (Anisimova et al., 2019; Li et al., 2012).

\section{7 | MMSCs proliferative test}

MMSCs $(0.2 \mathrm{ml})$ were plated onto the surface of steel samples that were placed in 24-well culture plates with the growth medium (1.8 ml) and incubated at $37^{\circ} \mathrm{C}$ in humidified atmosphere $2 \% \mathrm{CO}_{2}$ for 7 days. Cells in control were treated only with the growth medium. The cell colonization of samples was evaluated using light microscopy. The cell proliferation was measured in MTT test as described above. At the end of the assay, the media with MTT was removed, purple formazan reaction product was dissolved by adding $500 \mu \mathrm{L}$ DMSO and vibrated slightly for $10 \mathrm{~min}$, then $100 \mu \mathrm{L}$ solution was transferred to wells of a 96-well plate in triplicate. OD was measured using a plate rider MS Multiscan (Labsystem) at $540 \mathrm{~nm}$. OD baseline was determined using the MTT test on the first day of the experiment. The MMSC proliferation was calculated by the following formula (1):

$$
C P=\frac{O D_{\text {sample }}-O D_{\text {baseline }}}{O D_{\text {baseline }}} \times 100,
$$


where $\mathrm{CP}$-cell proliferation, \%; $\mathrm{OD}_{\text {sample }}-\mathrm{OD}$ after incubation cells with steel samples; $O D_{\text {baseline }}-$ mean value of $O D$ for baseline measurement.

\subsection{Cell apoptosis test}

The Annexin V Apoptosis Detection Kit (Novus, Littleton CO, USA) was used. Cells were prepared for the study in accordance with the manufacturer's instructions. The Annexin $\mathrm{V}(+)$ cells concentration was evaluated with BD FACS Canto II Cell Analyzer (Beckton Dickinson, New Jersey, USA) and analyzed with BD FACS Diva Software program (Beckton Dickinson, New Jersey, USA).

\section{9 | Statistical analysis}

These experiments were evaluated in triplicate at each of the designated times. The data were presented as a mean $(\mathrm{m})$ and mean deviation (M). One-way ANOVA and $t$ test analysis were used to calculate the $P$-value with Statistica ${ }^{\circledR} 6.0$ software. A $p$-value $<.05$ was considered to represent a statistically meaningful difference.

\section{RESULTS}

\section{1 | Microstructural characterization}

The microstructure of steels after ECAP at $400^{\circ} \mathrm{C}$ observed by transmission electron microscopy (TEM) is shown in Figure 1. Austenitic grain-subgrain structure with an average size of structural elements of $d=176 \pm 10 \mathrm{~nm}$ and fine deformation twins with a thickness of $d_{t w}=8 \pm 2 \mathrm{~nm}$ were found out in $316 \mathrm{~L}$ after ECAP at $400^{\circ} \mathrm{C}$ (Figure 1a,b). Austenitic grain-subgrain oriented structure with an average grain/subgrain size of $d=148 \pm 6 \mathrm{~nm}$ and deformation twins with a thickness of $d_{t w}=3.5 \pm 0.4 \mathrm{~nm}$ were found in $\mathrm{Cr}-\mathrm{Ni}$ - Ti stainless steel (Figure $1 \mathrm{c}-\mathrm{e}$ ). The average size of the structural elements was determined from dark-field images (Figure 1f). Point reflections on an annular electron diffraction patterns in the corresponding TEM
FIGURE 1 TEM micrographs of 316L stainless steel $(\mathrm{a}, \mathrm{b})$ and the $\mathrm{Cr}-\mathrm{Ni}-\mathrm{Ti}$ stainless steel ( $c-f)$ with deformation twins (b, d) after ECAP at $400^{\circ} \mathrm{C}$ with corresponding SAD patterns
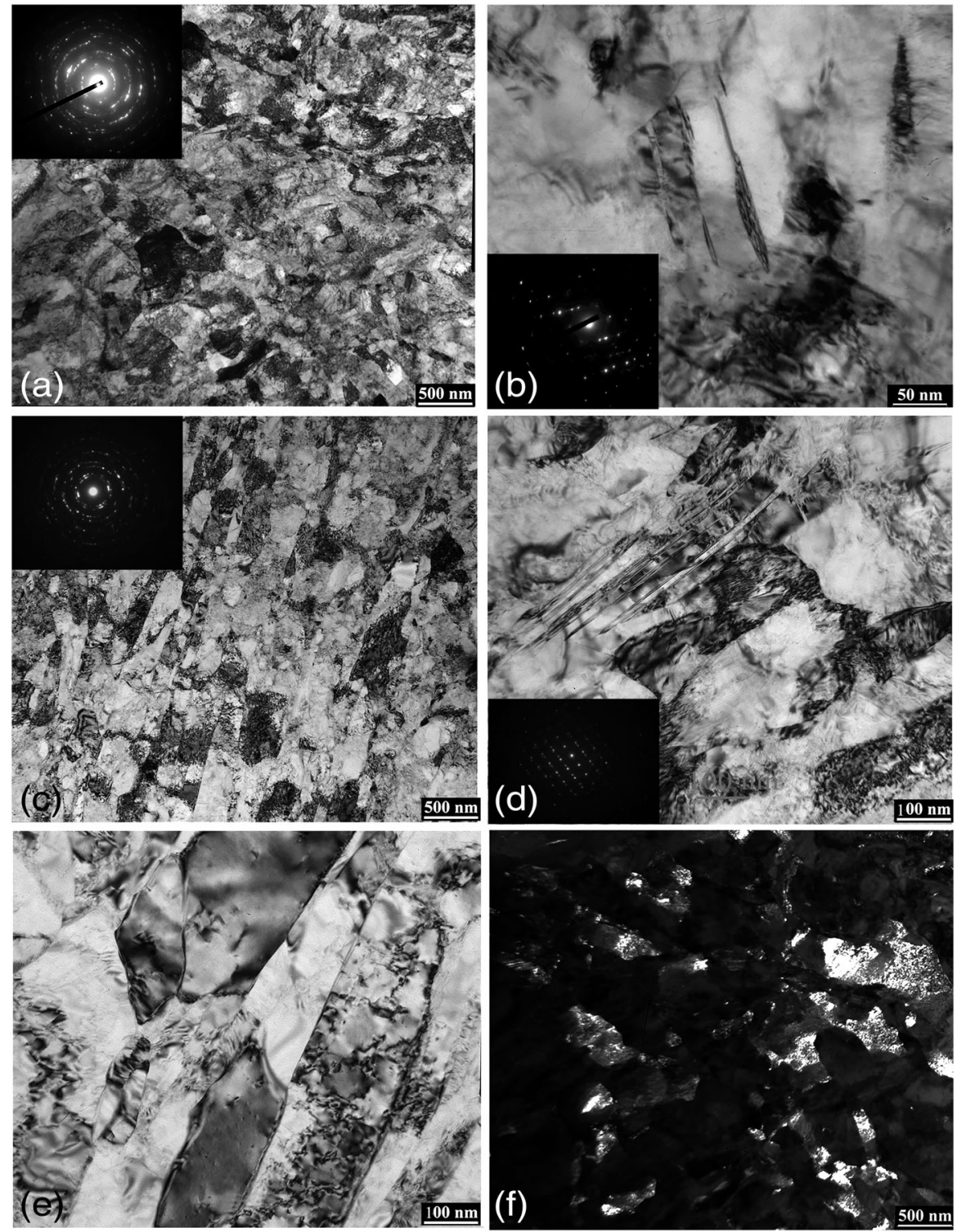
micrographs (Figure 1a-d), as well as a fringe contrast at the grain boundaries proved the presence of high-angle boundaries, that is, the grain structure (Figure 1e).

The average size of the structural elements in $316 \mathrm{~L}$ steel exceeded that of $\mathrm{Cr}-\mathrm{Ni}-\mathrm{Ti}$ stainless steel despite the larger applied strain (8 passes versus 6). This can be explained by the lower stacking-fault energy (SFE) of the metastable steel compared to the stable 316L steel at the same deformation temperature (Padilha, Plaut, \& Rios, 2003; Plaut, Herrera, Escriba, Rios, \& Padilha, 2007). Lower SFE impedes dislocation glide and mobility of dislocations, which increases strain hardening (strain resistance) (Zhao, Zhu, Liao, Horita, \& Langdon, 2006). The structure refining of 316 L steel occurs mostly through dislocation glide, rather than twinning.

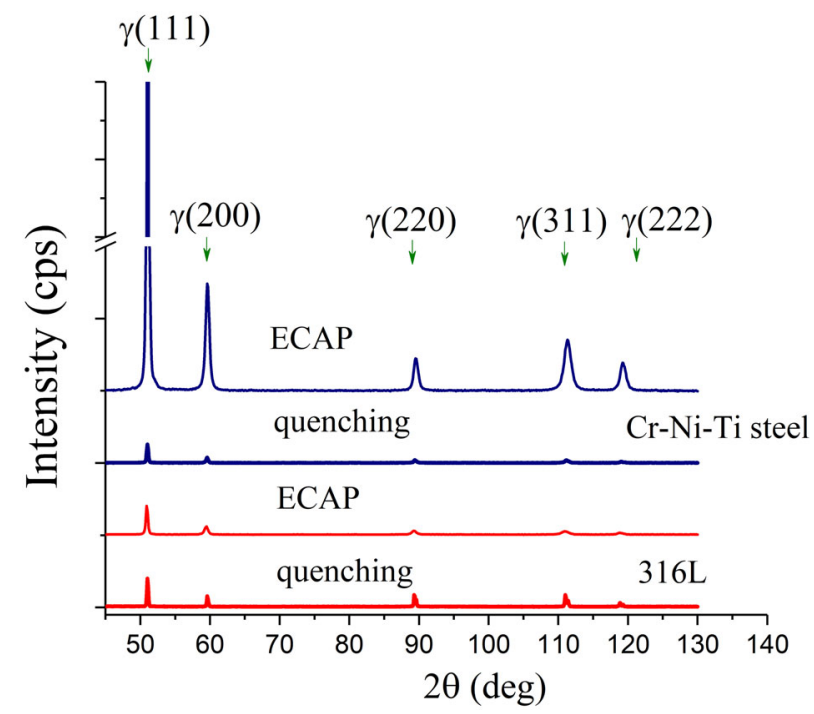

FIGURE 2 XRD of the $316 \mathrm{~L}$ and $\mathrm{Cr}-\mathrm{Ni}-\mathrm{Ti}$ steels subjected to ECAP at $400^{\circ} \mathrm{C}$
In the $\mathrm{Cr}-\mathrm{Ni}-\mathrm{Ti}$ stainless steel, the refinement of microstructure occurred due to the formation of shear bands (Figure 1c) with a high dislocation density inside and along the boundaries. Within the shear bands, the grain structure evolves owing to both the formation of cross bulkheads due to the accumulation of dislocations and the subdivision of grains by deformation twins (Figure 1d,e). Even after six ECAP passes at $400^{\circ} \mathrm{C}$, the microstructure of the $\mathrm{Cr}-\mathrm{Ni}-\mathrm{Ti}$ stainless steel remains oriented. The microstructure of $316 \mathrm{~L}$ steel is less oriented (Figure 1a), probably because of larger number of passes and greater SFE.

The X-ray diffraction (XRD) analysis confirmed the presence of a fully austenitic structure for both steels after deformation (Figure 2, Table 2). Two $\gamma$-phase lines of (111) and (222) were analyzed in order to determine the crystallite size and the values of microstrain $(\varepsilon)$ of the austenitic stainless steel samples after ECAP at $400^{\circ} \mathrm{C}$ (Table 3 ). Line profiles were approximated by Gauss function. The obtained crystallite sizes and $\varepsilon$ parameters made it possible to calculate the dislocation density. It was revealed that the dislocation density in $316 \mathrm{~L}$ steel is 1.7 times lower than that of $\mathrm{Cr}-\mathrm{Ni}-\mathrm{Ti}$ steel.

The higher crystallite size of $316 \mathrm{~L}$ steel corresponds to a slightly larger average size of the structural elements revealed by the TEM analysis. The sizes of the grains detected by TEM and the crystallite sizes determined by XRD are slightly different since the XRD analysis takes into account the subgrain structure, which is not always determined by electron microscopy.

\section{2 | Mechanical properties under static and cyclic loading}

ECAP of austenitic stainless $316 \mathrm{~L}$ and $\mathrm{Cr}-\mathrm{Ni}-\mathrm{Ti}$ steels leads to a significant increase in microhardness (HV). Figure 3a shows that HV increases by 2.1 times (from 1.9 to $4 \mathrm{GPa}$ ) for $316 \mathrm{~L}$ and by 1.9 times (from 2.1 to $3.9 \mathrm{GPa}$ ) for $\mathrm{Cr}-\mathrm{Ni}-\mathrm{Ti}$ steels.

TAB LE 2 Phase composition, crystallite size, microstrain, and dislocation density in the $\mathrm{Cr}-\mathrm{Ni}$ steels after ECAP at $400^{\circ} \mathrm{C}$ as revealed by $\mathrm{X}$-ray line profile analysis

\begin{tabular}{lllllll} 
Steel & Phase & Fraction $($ vol \%) & $a(\AA)$ & Crystallite size $(\AA)$ & $\varepsilon(\%)$ & $\rho, 10^{14}\left(\mathrm{~m}^{-2}\right)$ \\
\hline 316L & $\gamma$ & $100.0 \pm 0.014$ & $3.60219 \pm 0.00019$ & $1,250 \pm 114$ & $0.09 \pm 0.014$ & 0.098 \\
ECAP at $T=400^{\circ} \mathrm{C} . n=8$ & & & & & & \\
$\mathrm{Cr}-\mathrm{Ni}$-Ti steel ECAP at $T=400^{\circ} \mathrm{C} . n=6$ & $\gamma$ & $100.0 \pm 0.03$ & $3.59019 \pm 0.00019$ & $781 \pm 150$ & $0.122 \pm 0.033$ & 0.171 \\
\hline
\end{tabular}

TAB LE 3 Mechanical properties of $\mathrm{Cr}-\mathrm{Ni}$ stainless steels

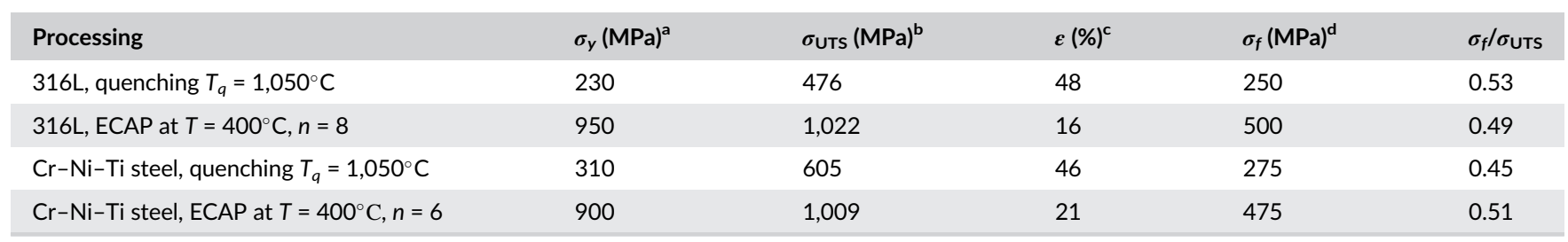

${ }^{\mathrm{a}} \sigma_{\mathrm{y}}$-yield stress.

${ }^{\mathrm{b}} \sigma_{\text {UTS }}-$ ultimate tensile strength.

${ }^{\mathrm{c}} \mathcal{c}$-total elongation.

${ }^{\mathrm{d}} \sigma_{f}$-fatigue limit. 
(a)

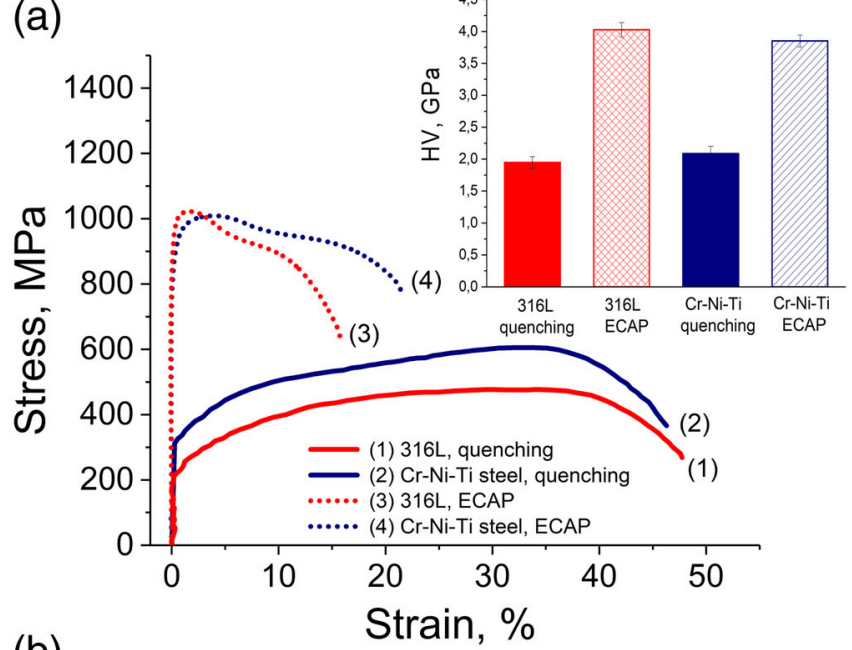

(b)

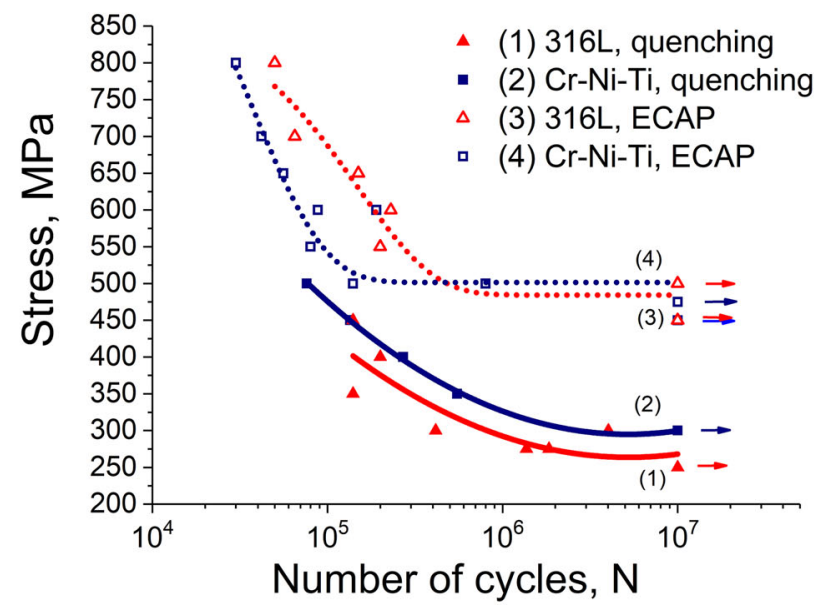

FIGURE 3 Mechanical properties of the austenitic stainless steels in the initial state $\left(1,050^{\circ} \mathrm{C}, 1 \mathrm{hr}\right.$, water quenching) and after ECAP at $400^{\circ} \mathrm{C}$; (a) tensile tests and (b) high-cycle fatigue tests

Tension curves of the austenitic stainless steels after ECAP are also shown in Figure 3a. The UFG structure considerably increases the strength characteristics of steels $\left(\sigma_{y} . \sigma_{\text {UTS }}\right)$ while maintaining satisfactory plasticity (Figure 3a, Table 2). The ultimate strength of 316L and $\mathrm{Cr}-\mathrm{Ni}-\mathrm{Ti}$ stainless steels increases by 2.1 and 1.7 times, and the yield strength-4.1 and 2.9 times, respectively, after ECAP at $400^{\circ} \mathrm{C}$ as compared to the initial state. Note here that the both steels subjected to ECAP exhibit almost the same strength, although the metastable $\mathrm{Cr}-\mathrm{Ni}-\mathrm{Ti}$ steel is characterized by somewhat larger ductility (Table 3).

An important criterion for assessing the stability of the structural state of a material and its performance under cyclic loads is a fatigue strength. The present study revealed a significant increase in the fatigue strength of ASS after ECAP at $400^{\circ} \mathrm{C}$ (Figure 3b). Table 3 shows the values of fatigue limits $\left(\sigma_{f}\right)$ under the high-cycle loading of samples of the investigated steels in initial quenched state and after ECAP. $\sigma_{f}$ of the steel samples processed by ECAP at $400^{\circ} \mathrm{C}$ is almost the same. The fatigue limit amounts to $475 \mathrm{MPa}$ and $500 \mathrm{MPa}$ for $316 \mathrm{~L}$ and $\mathrm{Cr}-\mathrm{Ni}-\mathrm{Ti}$ steels, respectively, which is 2 and 1.7 times

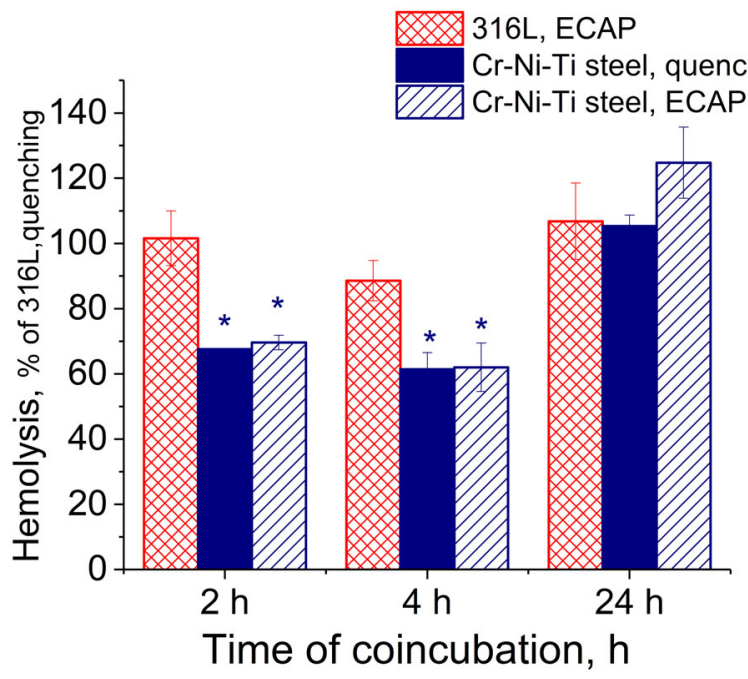

FIGURE 4 Hemolysis ratios for 316 after ECAP, $\mathrm{Cr}$-Ni-Ti steel after quenching and $\mathrm{Cr}-\mathrm{Ni}-\mathrm{Ti}$ steel after ECAP versus $316 \mathrm{~L}$ after quenching, ${ }^{*} p<.05$ versus $316 \mathrm{~L}$ after quenching, $* * p<.05 \mathrm{Cr}-\mathrm{Ni}-\mathrm{Ti}$ steel after ECAP versus $\mathrm{Cr}-\mathrm{Ni}-\mathrm{Ti}$ steel after quenching

higher than the fatigue strength in the initially quenched condition. The fatigue ratio $\sigma_{f} / \sigma_{\text {UTS }}$ as an indicator of the working capacity after ECAP is only slightly reduced for $316 \mathrm{~L}$ steel and even increased for $\mathrm{Cr}-\mathrm{Ni}-\mathrm{Ti}$ steel. This can be explained by the fact that the additional strain hardening of $\mathrm{Cr}-\mathrm{Ni}-\mathrm{Ti}$ steel is associated with not only the rearrangement of the dislocation substructure, but also with the formation of deformation induced martensite in the local metal zones (Dobatkin et al., 2018).

\section{3 | Biocompatibility in vitro}

In the hemolysis tests, three samples of the studied steels, namely, 316 L steel after ECAP, $\mathrm{Cr}-\mathrm{Ni}-\mathrm{Ti}$ steel after quenching and $\mathrm{Cr}-\mathrm{Ni}-\mathrm{Ti}$ steel after ECAP, were compared with the $316 \mathrm{~L}$ steel after quenching. The hemolytic activity of all samples was nearly the same $(p>.05)$ after incubation for $24 \mathrm{hr}$ (Figure 4). It is important to note that for time of incubation less than $4 \mathrm{hr}$ the $\mathrm{Cr}-\mathrm{Ni}$ - $\mathrm{Ti}$ steel-induced hemolysis rate was less in comparison with $316 \mathrm{~L}$ activity $(p<.05)$ : on $30 \%$ or more. The ECAP treatment of steels did not lead to significant change in the hemolytic activity compared to austenitic samples of $316 \mathrm{~L}$ and $\mathrm{Cr}-\mathrm{Ni}-\mathrm{Ti}$ steels after quenching $(p>.05)$.

The cytotoxicity of these samples was very close to the activity of $316 \mathrm{~L}$ samples after quenching $(p>.05)$ (Figure 5). Also, there was no significant difference in the characteristics of ECAP-treated samples in comparison with the samples in coarse-grained sate $(p>.05)$.

\subsection{MMSCs proliferation test}

In the MMSCs proliferation test steels samples, namely, 316L steel after ECAP, $\mathrm{Cr}-\mathrm{Ni}$-Ti steel after quenching and $\mathrm{Cr}-\mathrm{Ni}$-Ti steel after ECAP were compared with the $316 \mathrm{~L}$ steel after quenching. The data presented in Figure 6 did not reveal a significant difference in the 


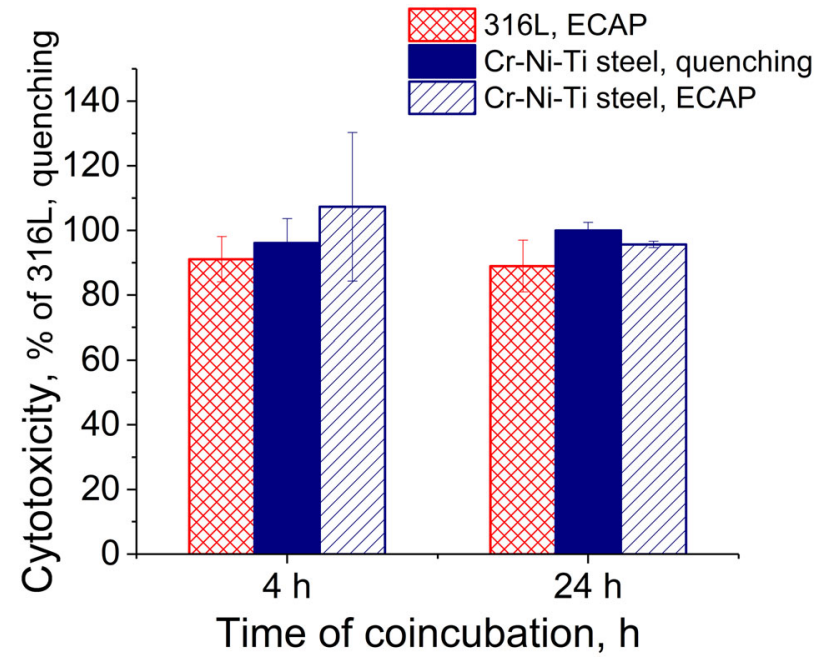

FIGURE 5 Cytotoxicity ratios for 316L after ECAP, Cr-Ni-Ti steel after quenching and $\mathrm{Cr}-\mathrm{Ni}-\mathrm{Ti}$ steel after ECAP versus 316L after quenching, $* p<.05$ versus $316 \mathrm{~L}$, quenching, $* * p<.05 \mathrm{Cr}-\mathrm{Ni}-\mathrm{Ti}$ steel ECAP versus $\mathrm{Cr}-\mathrm{Ni}-\mathrm{Ti}$ steel, quenching

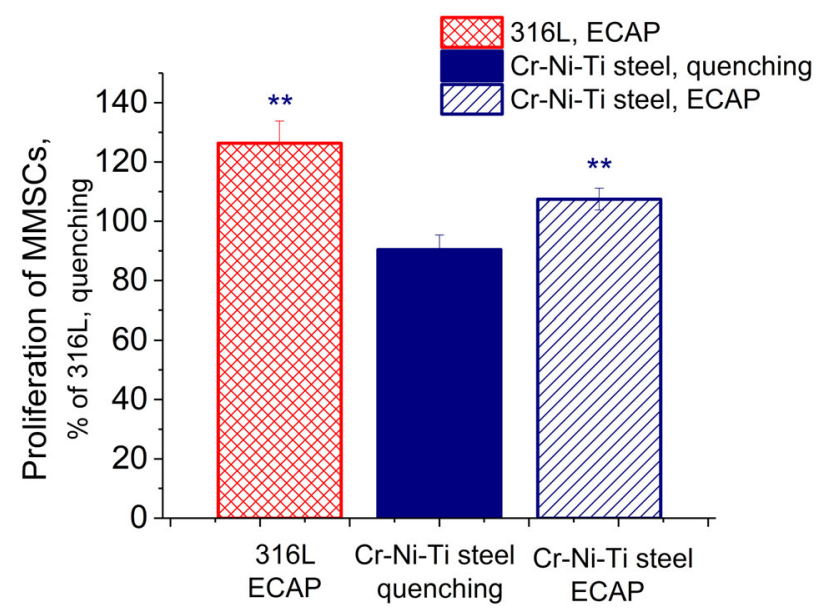

FIGURE 6 Proliferation ratios for 316L after ECAP, $\mathrm{Cr}-\mathrm{Ni}-\mathrm{Ti}$ steel after quenching and $\mathrm{Cr}-\mathrm{Ni}-\mathrm{Ti}$ steel after ECAP versus $316 \mathrm{~L}$ after quenching, $* p<.05$ versus $316 \mathrm{~L}$ after quenching, $* * p<.05 \mathrm{Cr}-$ $\mathrm{Ni}-\mathrm{Ti}$ steel after ECAP versus $\mathrm{Cr}-\mathrm{Ni}-\mathrm{Ti}$ steel after quenching

proliferation of MMSCs $(p>.05)$. It was noted that the proliferation of MMSC on samples of the ECAP-treated $316 \mathrm{~L}$ and $\mathrm{Cr}-\mathrm{Ni}-\mathrm{Ti}$ steels was slightly higher compared with counterparts in coarse-grained sate: by $26 \%$ (316L after quenching vs. 316L after ECAP, $p=.044$ ) and by $17 \%(\mathrm{Cr}-\mathrm{Ni}-\mathrm{Ti}$ steel after ECAP vs. $\mathrm{Cr}-\mathrm{Ni}-\mathrm{Ti}$ steel after quenching, $p=.038$ ).

\subsection{Cell apoptosis test}

A special series of experiments were devoted to the effect of the steel samples on the induction of cell apoptosis (programmed death of cells) associated with Annexin $\mathrm{V}$ expression in cell suspension. The steel samples were incubated with ML for $4 \mathrm{hr}$ and then the concentration of Annexin $\mathrm{V}(+)$ cells was counted (Table 4). The obtained data did not show significant changes in the Annexin $\mathrm{V}(+)$ cells concentration under the influence of the studied steel samples $(p>.05)$. Accordingly, no difference was found between the activity of samples of $316 \mathrm{~L}$ after ECAP, $\mathrm{Cr}-\mathrm{Ni}-\mathrm{Ti}$ steel after quenching and $\mathrm{Cr}-\mathrm{Ni}-\mathrm{Ti}$ steel after ECAP in comparison with the sample of $316 \mathrm{~L}$ in quenched state $(p>$.05). There were also no differences in the effect for the ECAPtreated steel samples as compared with coarse-grained counterparts $(p>.05)$.

\section{4 | DISCUSSION}

In this study, stainless $316 \mathrm{~L}$ and $\mathrm{Cr}-\mathrm{Ni}-\mathrm{Ti}$ steels in quenched state and after ECAP were investigated. The study revealed that ECAP at $400^{\circ} \mathrm{C}$ leads to the formation of ultrafine-grained structure in both austenitic stainless steels with an average size of structural elements of about $200 \mathrm{~nm}$ and the fine deformation twins (Figure 1). The selected ECAP temperature exceeded the onset temperature of the formation of strain-induced martensite. This can explain a fully austenitic structure even in metastable $\mathrm{Cr}-\mathrm{Ni}$ - Ti stainless steel (Figure 2). Grain refinement had great influence on the mechanical strength, to improving tensile strength and fatigue properties of both steels (Figure 3). Further analysis showed that both steels had practically identical microstructural features and, as a result, strength properties. The grain refinement by means of large strain deformation results commonly in substantial strengthening and significant degradation of plasticity (Tikhonova, Kaibyshev, \& Belyakov, 2018). However, the present ultrafine-grained (UFG) steels differ from other UFG alloys processed by severe plastic deformation by remarkable plasticity with total elongation above $15 \%$. Sufficient ductility has been considered as an important property of the biomedical devices (Nune et al.,

TAB LE 4 The concentration of Annexin V (+) cells after incubation with samples of 316L and $\mathrm{Cr}-\mathrm{Ni}-\mathrm{Ti}$ steels after quenching, and ECAP in comparison with intact cells (Control). Incubation time $4 \mathrm{hr}$

\begin{tabular}{|c|c|c|c|c|c|}
\hline Steel & $M$ & m & \multicolumn{3}{|l|}{$\mathrm{p}$} \\
\hline 316L, quenching & 1.9 & 0.64 & 0.218 & - & - \\
\hline 316L, ECAP & 1.5 & 0.31 & 0.203 & 0.611 & - \\
\hline $\mathrm{Cr}-\mathrm{Ni}-\mathrm{Ti}$ steel, quenching & 1.4 & 0.8 & 0.533 & 0.656 & - \\
\hline $\mathrm{Cr}-\mathrm{Ni}-\mathrm{Ti}$ steel, ECAP & 1.6 & 1.1 & 0.531 & 0.823 & 0.892 \\
\hline
\end{tabular}


2018). The beneficial strength-ductility combination in the present UFG steels resulted from elevated temperature of ECAP that enhanced recovery of the work-hardened dislocation substructures during processing and retained the ability of the steels to mechanical twinning as seen in Figure 1. Thus, the present study opens up a promising alternative approach for the development of advanced materials for biomedical applications in addition to the phase reversion approach, which has been recently proposed to produce multifunctional bio-implant materials (Nune \& Misra, 2016).

Since the chemical composition of the steels was different from each other, the significant difference in chemical behavior and biological response to these steels was expected. However, both austenitic 316 $\mathrm{L}$ and $\mathrm{Cr}-\mathrm{Ni}-\mathrm{Ti}$ stainless steels after ECAP showed nearly the same biocompatibility in comparison to $316 \mathrm{~L}$ with coarse-grained structure. In particular, undesirable changes in the hemolysis ratio, cytotoxicity, proliferation and concentration of Annexin V-associated apoptotic cells were not detected for steel samples after ECAP. Moreover, the proliferation of MMSC was improved on the ECAP samples (Figure 6). Subsequent application of electrochemical grooving of the ECAP sample surfaces is expected to be quite favorable for further acceleration of the cellular activity (Venkatsurya, Thein-Han, Misra, Somani, \& Karjalainen, 2010).

It was reported that an ultrafine-grained structure in stainless steels imparts significantly higher oxidation resistance than conventional coarse grain counterparts of the same chemical composition (Gupta \& Birbilis, 2015). It can be explained by greater $\mathrm{Cr}$ diffusion and ease of formation of compact $\mathrm{Cr}$-oxide layer in ultrafine-grained steels. It was noted that for them the passive film is more stable, compact and contains a lower defect density, while the $\mathrm{Cr}$ content in the passive film was higher with equal bulk $\mathrm{Cr}$ content.

In this work, the same chromium composition of the of $316 \mathrm{~L}$ and $\mathrm{Cr}-\mathrm{Ni}-\mathrm{Ti}$ steels led to the equal changes in the oxide layer after ECAP. As a result, ECAP did not cause deterioration in the biocompatibility, but even improved the proliferative activity of MMSCs.

Nevertheless, according to the results of short-term incubation (4 hr or less) (Figure 4), it was found that under the influence of $\mathrm{Cr}$ $\mathrm{Ni}$-Ti steel samples, the hemolysis ratio is lower compared to that of austenitic 316 L steel. In this case, hemolytic activity is equally low for both coarse-grained and ultrafine-grained $\mathrm{Cr}-\mathrm{Ni}-\mathrm{Ti}$ steel. Therefore, the reason should be in the chemical composition, most likely in a lower $\mathrm{Ni}$ content in austenitic stainless $\mathrm{Cr}-\mathrm{Ni}-\mathrm{Ti}$ steel compared to 316L steel. This difference disappears with increasing the incubation time, perhaps because with the development of corrosion.

\section{5 | CONCLUSIONS}

The study considers the ultrafine-grained austenitic stainless $316 \mathrm{~L}$ and $\mathrm{Cr}-\mathrm{Ni}$-Ti steels as a promising material for medical use. The biocompatibility of studied samples with the ultrafine grain structure after ECAP does not deteriorate in comparison with medical 316L steel in coarse-grained state, while the MMSCs proliferation enhances. At the same time, ECAP can contribute to significant improvement of the performance and weight reduction of medical devices, which is especially important for the creation of implanted prostheses for replacement of skeletal defects, due to significant increase in the specific strength and fatigue properties of steels.

\section{ACKNOWLEDGMENTS}

The work was supported by the Russian Foundation for Basic Research (grant 16-08-00365-a) and by the Basic Research Program of the Presidium of the Russian Academy of Sciences $37 \mathrm{P}$. Fatigue tests were carried out within the governmental task 075-00746-19-00.

\section{ORCID}

Olga V. Rybalchenko (D) https://orcid.org/0000-0002-0403-0800

\section{REFERENCES}

Anisimova, N., Kiselevskiy, M., Martynenko, N., Straumal, B., WillumeitRömer, R., Dobatkin, S., \& Estrin, Y. (2019). Cytotoxicity of biodegradable magnesium alloy WE43 to tumor cells in vitro: Bioresorbable implants with antitumor activity? Journal of Biomedical Materials Research. Part B, 9999B, 1-7.

Davies, J. R. (Ed.). (2003). Metallic materials. Handbook of materials for medical devices. ASM international (pp. 21-50). Ohio: Materials Park.

Dobatkin, S. V., Rybal'chenko, O. V., \& Raab, G. I. (2007). Structure formation, phase transformations and properties in $\mathrm{Cr}-\mathrm{Ni}$ austenitic steel after equal-channel angular pressing and heating. Materials Science and Engineering A, 463, 41-45.

Dobatkin, S. V., Skrotzki, W., Rybalchenko, O. V., Terent'ev, V. F., Belyakov, A. N., Prosvirnin, D. V., ... Zolotarev, E. V. (2018). Structural changes in metastable austenitic steel during equal channel angular pressing and subsequent cyclic deformation. Materials Science and Engineering A, 723, 141-147.

Dong, F. Y., Zhang, P., Pang, J. C., Chen, D. M., Yang, K., \& Zhang, Z. F. (2013). Optimizing strength and ductility of austenitic stainless steels through equal-channel angular pressing and adding nitrogen element. Materials Science and Engineering A, 587, 185-1917.

Faghihi, S., Azari, F., Zhilyeav, A. P., Vali, H., \& Tabrizian, M. (2007a). Nanostructuring of a titanium material by high-pressure torsion improves pre-osteoblast attachment. Advanced Materials, 19, 1069-1073.

Faghihi, S., Azari, F., Zhilyeav, A. P., Vali, H., \& Tabrizian, M. (2007b). Cellular and molecular interactions between MC3T3-E1 pre-osteoblasts and nanostructured titanium produced by high-pressure torsion. Biomaterials, 28, 3887-3895

Gupta, R. K., \& Birbilis, N. (2015). The influence of nanocrystalline structure and processing route on corrosion of stainless steel: A review. Corrosion Science, 92, 1-15.

Huang, C. X., Yang, G., Gao, Y. L., Wu, S. D., \& Zhang, Z. F. (2008). Influence of processing temperature on the microstructures and tensile properties of 304L stainless steel by ECAP. Materials Science and Engineering $A, 485,643-650$

Iwahashi, Y., Horita, Z., Nemoto, M., \& Langdon, T. G. (1997). An investigation of microstructural evolution during equal-channel angular pressing. Acta Materialia, 45, 4733-4741.

Iwahashi, Y., Wang, J., Horita, Z., Nemoto, M., \& Langdon, T. G. (1996). Principle of equal-channel angular pressing for the processing of ultrafine grained materials. Scripta Materialia, 35(2), 143-146.

Kay, S., Thapa, A., Haberstroh, K. M., \& Webster, T. J. (2002). Nanostructured polymer/nanophase ceramic composites enhance osteoblast and chondrocyte adhesion. Tissue Engineering, 8(5), 753. 
Li, Y., Wen, C., Mushahary, D., Sravanthi, R., Harishankar, N., Pande, G., \& Hodgson, P. (2012). Mg-Zr-Sr alloys as biodegradable implant materials. Acta Biomaterialia, 8(8), 3177-3188.

Mantripragada, V. P., Lecka-Czernik, B., Ebraheim, N. A., \& Jayasuriya, A. C. (2013). An overview of recent advances in designing orthopedic and craniofacial implants. Journal of Biomedical Materials Research Part A, 101(11), 3349-3364.

McManus, A. J., Doremus, R. H., Siegel, R. W., \& Bizios, R. J. (2005). Evaluation of cytocompatibility and bending modulus of nanoceramic/polymer composites. Journal of Biomedical Materials Research Part A, 72, 98-106.

Misra, R. D. K., Thein-Han, W. W., Pesacreta, T. C., Hasenstein, K. H., Somani, M. C., \& Karjalainen, L. P. (2009a). Cellular response of preosteoblasts to nanograined/ultrafine-grained structures. Acta Biomaterialia, 5, 1455-1467.

Misra, R. D. K., Thein-Han, W. W., Pesacreta, T. C., Hasenstein, K. H., Somani, M. C., \& Karjalainen, L. P. (2009b). Favorable modulation of pre-osteoblast response to nanograined/ultrafine-grained structures in austenitic stainless steel. Advanced Materials, 21, 1280-1285.

Muley, S. V., Vidvans, A. N., Chaudhari, G. P., \& Udainiya, S. (2016). An assessment of ultrafine grained $316 \mathrm{~L}$ stainless steel for implant applications. Acta Biomaterialia, 30, 408-419.

Narayan, R. (Ed.). (2009). Biomedical materials. Boston: Springer Science +Business Media. LLC 566 p.

Niinomi, M., Nakai, M., \& Hieda, J. (2012). Development of new metallic alloys for biomedical applications. Acta Biomaterialia, 8, 3888-3903.

Nune, K. C., \& Misra, R. D. K. (2016). Biological activity of nanostructured metallic materials for biomedical applications. Materials and Technologies, 31, 772-781.

Nune, K. C., Montes, I., Injeti, V. S. Y., Somani, M. C., \& Misra, R. D. K. (2018). The determining role of nanoscale mechanical twinning on cellular functions of nanostructured materials. Journal of the Mechanical Behavior of Biomedical Materials, 88, 185-195.

Okazaki, Y., \& Goth, E. (2008). Metal release from stainless steel Co- $\mathrm{Cr}$ $\mathrm{Mo}-\mathrm{Ni}-\mathrm{Fe}$ and $\mathrm{Ni}-\mathrm{Ti}$ alloys in vascular implants. Corrosion Science, 50 , 3429-3438.

Padilha, A. F., Plaut, R. L., \& Rios, P. R. (2003). Annealing of cold-worked austenitic stainless steels. ISIJ International, 43(2), 135-143.

Plaut, R. L., Herrera, C. D., Escriba, M. P., Rios, R., \& Padilha, A. F. (2007). A short review on wrought austenitic stainless steels at high temperatures: Processing, microstructure, properties and performance. Materials Research, 10(4), 453-460.

Senatov, F., Anisimova, N., Kiselevskiy, M., Kopylov, A., Tcherdyntsev, V., \& Maksimkin, A. (2017). Polyhydroxybutyrate/hydroxyapatite highly porous scaffold for small bone defects replacement in the nonloadbearing parts. Journal of Bionic Engineering, 14(4), 648-658.

Teoh, S. H. (2000). Fatigue of biomaterials: A review. International Journal of Fatigue, 22(10), 825-837.
Thapa, A. T., Webster, J., \& Haberstroh, K. M. (2003). Polymers with nanodimensional surface features enhance bladder smooth muscle cell adhesion. Journal of Biomedical Materials Research. Part A, 67, 1374-1383.

Thierry, B., Merhi, Y., Bilodeau, L., Trépanier, C., \& Tabrizian, M. (2002). Nitinol versus stainless steel stents: Acute thrombogenicity study in an ex vivo porcine model. Biomaterials, 23, 2997-3005.

Tikhonova, M., Kaibyshev, R., \& Belyakov, A. (2018). Microstructure and mechanical properties of austenitic stainless steels after dynamic and post-dynamic recrystallization treatment. Advanced Engineering Materials, 20 Art.No. 1700960, 1-27.

Ueno, H., Kakihata, K., Kaneko, Y., Hashimoto, S., \& Vinogradov, A. (2011). Enhanced fatigue properties of nanostructured austenitic SUS 316L stainless steel. Acta Materialia, 59, 7060-7069.

Valiev, R. Z., \& Langdon, T. G. (2006). Principles of Equal-Channel angular pressing as a processing tool for grain refinement. Progress in Materials Science, 51(7), 881-981.

Venkatsurya, P. K. C., Thein-Han, W. W., Misra, R. D. K., Somani, M. C., \& Karjalainen, L. P. (2010). Advancing nanograined/ultrafine-grained structures for metal implant technology: Interplay between grooving of nano/ultrafine grains and cellular response. Materials Science and Engineering: C, 30, 1050-1059.

Webster, T. J., Ergun, C., Doremus, R. H., Siegel, R. W., \& Bizios, R. (2000). Enhanced functions of osteoblasts on nanophase ceramics. Biomaterials, 21, 1803

Webster, T. J., Siegel, R. W., \& Bizios, R. (1999). Enhanced osteoclast-like cell functions on nanophase ceramics. Biomaterials, 20, 1221.

Webster, T. J., \& Smith, T. A. (2005). Increased osteoblast function on PLGA composites containing nanophase titania. Journal of Biomedical Materials Research. Part A, 74, 677-686.

Yamamoto, A., Kohama, Y., Kuroda, D., \& Hanawa, T. (2004). Cytocompatibility evaluation of $\mathrm{Ni}$-free stainless steel manufactured by nitrogen adsorption treatment. Materials Science and Engineering: $C$, 24, 737-743.

Zhao, Y. H., Zhu, Y. T., Liao, X. Z., Horita, Z., \& Langdon, T. G. (2006). Tailoring stacking fault energy for high ductility and high strength in ultrafine grained cu and its alloy. Applied Physics Letters, 89, 121906.

How to cite this article: Rybalchenko OV, Anisimova NY, Kiselevsky MV, et al. The influence of ultrafine-grained structure on the mechanical properties and biocompatibility of austenitic stainless steels. J Biomed Mater Res. 2020;108: 1460-1468. https://doi.org/10.1002/jbm.b.34494 